\title{
Editorial:
}

\section{The Gift of Education}

\author{
Julian Kitchen \\ Editor \\ Brock University
}

One of the greatest gifts is the opportunity to learn. Many, blessed with rich learning opportunities at home and in school, take this for granted. Many here and around the world are not so fortunate.

Gift Days, a picture book by children's author Kari-Lynn Winters (2012), is a powerful reminder of the limits to educational opportunity and a testament to how caring individuals can give the gift of learning in even the most adverse circumstances. Nassali, an African girl unable to attend school, fulfils her wish to read thanks to the gift days offered by her brother, Matovu. As educators, we are uniquely positioned to provide young people with gift days of wonder, knowledge and understanding.

"Please Matovu, tell me what the squiggles say," Nassali asks in Gift Days. In the first article in this issue, "The Missing Tooth: Case Illustrations of a Child's Assembled, Out-ofSchool Authorship," Kari-Lynn Winters draws on theories of social semiotics, New Literacy Studies (NLS), and critical positioning to explore how a child's modes of meaning-making and socio-cultural environment can contribute to literacy and, ultimately, authorship. Through this powerful and deeply personal piece involving interactions with her young son, Winters invites us to think of the gift of literacy in ways that take into "account children's social lives, their personal relations and connections, and their authentic ways of creating and communicating meaning."

Nassali says, "I will teach myself to read" but is unable to do so until she receives help. Most of us learn better when other adapt the lessons to our the lives we lead. In "Food Chains, Frenemies, and Revenge Fantasies: Relating Fiction to Life in a Girls' Book Club," Nancy Taber, Vera Woloshyn, and Laura Lane explore the complex ways in which the girls negotiate their everyday lives by studying discussions about Dork Diaries in a book club. While the girls were capable of reading the book on their own, the structured activities helped them "illuminate their own lives, giving the group the opportunity to critique food chains, frenemies, and revenge fantasies. In each case, the girls first validated and then critiqued these aspects of their lives, moving away from an unquestioned acceptance of meanness in the food chain." This article reinforces the importance of educators as guides to deeper forms of literacy, social understanding, and authorship among learners.

"Maama always said an education is the path to a better life," Nassali recalls in Gift Days. Parents and teachers are powerful influences who can help students along that path. In "Honouring Roles: The Story of a Principal and a Student," Jerome Cranston explores the principal-student dynamic through a narrative inquiry into his interactions with a student during his time as a principal. Cranston argues that "school leadership should be focused on developing 
the relationships that support student and teacher learning rather than narrowly concentrating on technocratic approaches to managing things."

Every day is a potential gift day. Teacher educators are blessed with the opportunity to prepare teachers who can make a difference in the lives of children. The final three papers are testaments to the possibilities when teacher educators strive to deeply engage teacher candidates.

Teaching is a challenging profession, especially for teachers motivated to go the extra mile for their students. John Vitale, in "The Perfect Storm: Stress, Anxiety, and Burnout in the Secondary School Music Classroom," reminds us that we must take time to care for ourselves in order to offer students the gift of education. Vitale investigates the stress, anxiety, and burnout he experienced teaching music. For Vitale, transitioning from teacher to teacher educator, this process was valuable preparation for his future role. He writes, "I have much more insight and knowledge into the demanding role of the secondary school music teacher, which I can pass on and share with my students."

Lorayne Robertson and Janette Hughes are interested in developing critical literacy and promoting social justice. In "Surfacing the Assumptions: Pursuing Critical Literacy and Social Justice in Preservice Teacher Education," they examine how new literacies and technologysupported learning can be directed toward social and educational change. As they puzzle over their successes and struggles pedagogical innovators, they realized that new literacies and technologies need to become central themes in the learning of teacher candidates, not just vehicles to support critical literacy and social justice. This is a gift that may lead to better days for teacher candidates and the students they will eventually teach.

To make each school day a gift day, Nancy Maynes and Blaine E. Hatt argue in "Shifting the Focus to Student Learning: Characteristics of Effective Teaching Practice as Identified by Experienced Pre-service Faculty Advisors," teachers "need to make each instructional decision on the basis of its impact on student learning." In this article, they identify and examine instruments and processes for teacher growth. In their ongoing work, they are exploring ways of identifying these characteristics in hiring and developing them in teacher education and professional development.

In Gift Days, the gift of education led Nassali to university. I hope that the articles in this issue of Brock Education will inspire us as educators and teacher educators to make each school day a gift day.

\section{References}

Winters, K.-L. (2012). Gift days. Markham, ON: Fitzhenry \& Whiteside.

Brock Education, Vol, 22, No. 1 Fall 2012, 1-2. 